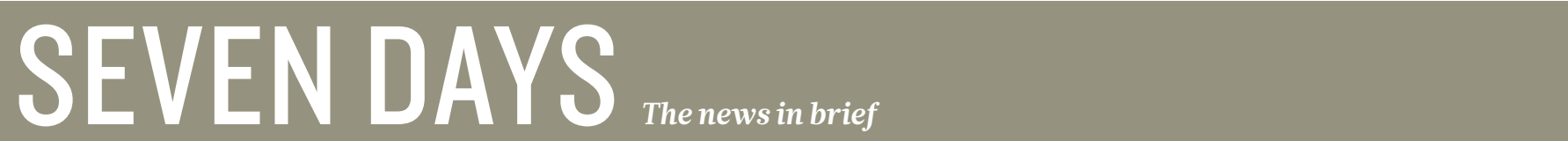

POLICY

\section{Vaccine letter}

More than 350 US

medical and professional organizations have sent a letter to President Donald Trump to assure him that vaccines are safe. The

7 February letter is a response to Trump's tweets and comments suggesting that certain vaccines are linked to autism. Signatories cite some 40 studies showing that vaccines are safe and that their ingredients have no link to autism. In January, Trump met Robert F. Kennedy Jr, an environmental attorney and outspoken vaccine critic, to discuss the creation of a national commission on the discredited link.

\section{Human gene editing}

A long-awaited report from the US National Academies of Science, Engineering, and Medicine has recommended that scientists should in future be allowed to make genetic modifications to human embryos destined for implantation in the womb, to eliminate genetic diseases such as sickle-cell anaemia or cystic fibrosis. But the 14 February report said that this would be acceptable only when gene-editing techniques are advanced enough to be used in people, and once strict restrictions and regulations are in place. See go.nature. com/213jwcr for more.

\section{Homeopathy blow}

The Russian Academy of Sciences is the latest body to officially declare homeopathy unscientific and ineffective.

Homeopathic medicine contradicts "known chemical, physical and biological laws" and should have no place in Russia's national health-care system, the academy's commission

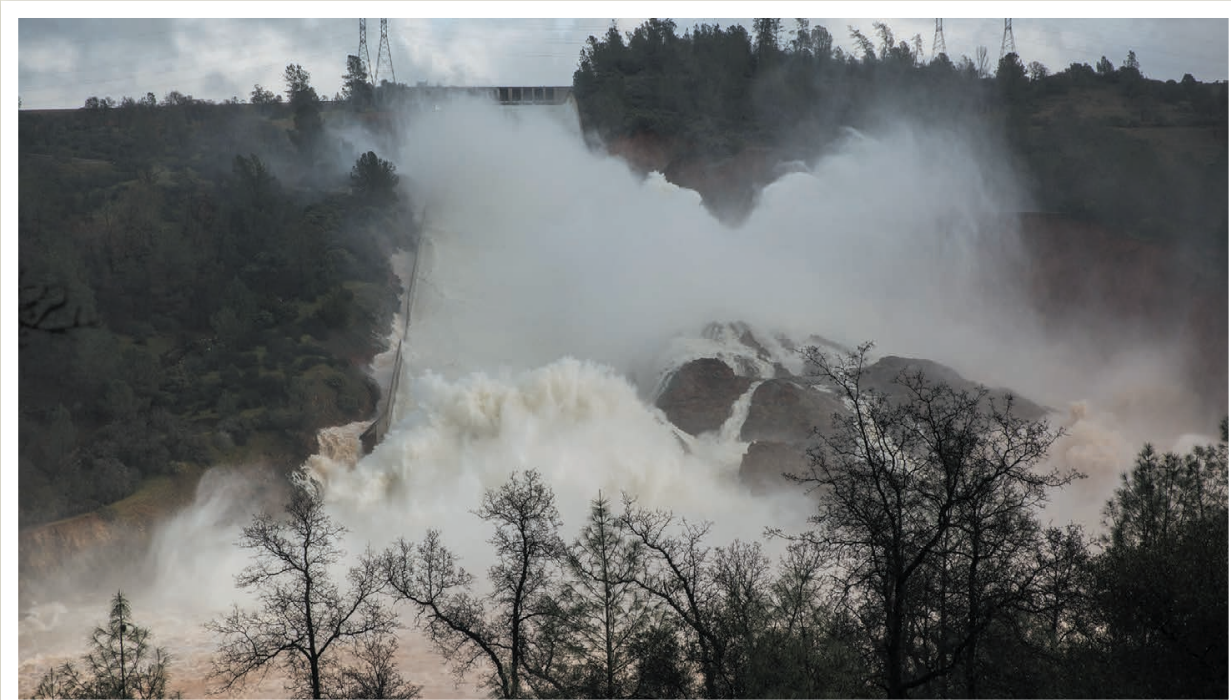

\section{Looming dam failure sparks evacuation}

Nearly 200,000 people living downstream of the Oroville Dam (pictured) in northern California were ordered to evacuate on 12 February after officials determined that an emergency overflow area - a last-resort measure to disperse water overflowing from the reservoir - was on the verge of failure. A wet winter has helped to alleviate a long-running drought in California, but heavy rains pushed the reservoir to its limits, also damaging the main concrete spillway that usually carries overflow. As of 13 February, officials reported that the danger had receded, although the evacuation order remained in place. The dam is the tallest in the United States. against pseudoscience and falsification of scientific research stated in a memorandum issued on 6 February. It called on the health ministry and drug-regulatory bodies to introduce mandatory labelling of homeopathic drugs and therapies, indicating their lack of proven efficacy.

The US Federal Trade Commission made similar recommendations last November.

\section{FUNDING}

\section{Biomed windfall}

The Chan Zuckerberg

Biohub, a biomedical research initiative created by Facebook co-founder Mark Zuckerberg and his wife, paediatrician Priscilla Chan, announced the winners in its first round of funding on 8 February. Forty-seven scientists from three Californian universities involved in the initiative will receive up to US $\$ 1.5$ million each in the next five years for 'risky' research ranging from microbial genomics to applied neurosciences. See page 280 for more.

\section{Cancer wins}

Cancer Research UK announced on 10 February the award of $£ 71$ million (US\$89 million) to four scientific teams that will address the charity's "grand challenges" in cancer research. The winners will develop 3D maps of tumours, discover new carcinogens by studying patterns in DNA mutation, and establish biomarkers for breast cancer. And on 14 February, the Royal Swedish Academy of Sciences announced the winners of the first Sjöberg prize for cancer research. US-based scientists James Allison and Tony Hunter share \$1 million for their work on cellular processes leading to new cancer drugs.

\section{PUBLISHING}

\section{Elsevier access}

Science publisher Elsevier has decided to restore online access to journals for dozens of German institutions that cancelled their subscriptions at the end of last year. Anticipating a nationwide licensing deal, about 60 universities and research institutes had not 
亗 automatically renewed their

individual subscriptions. But

negotiations between the

German library consortium

DEAL and the Amsterdam-

based publisher failed owing

to disagreements over

licensing costs and open access, and thousands of scientists in Germany were left unable to read hundreds of journals online. "The continuing access for the affected institutions will be in place while goodfaith discussions about a nationwide contract carry on," Elsevier said on 13 February.

\section{FACILITIES}

\section{Campus criticized}

Plans to establish a science super-campus near Paris suffer from poor governance and lack of an overall strategy, French government auditors said in their annual report, released on 8 February. The planned $€ 5$.3-billion (US\$5.7-billion) Paris-Saclay science cluster was supposed to rival the world's top research universities, such as the Massachusetts Institute of Technology. But auditors say that the vision of a large integrated research university is being watered down. Despite the huge investment, the cluster risks remaining a mere grouping of institutes without "real coherence and international visibility", they warn. See go.nature. com/2lfglum for more.

\section{PEOPLE \\ Rosling dies}

Hans Rosling, a Swedish epidemiologist famous for his charismatic talks and presentations, died on 7 February aged 68. Rosling, who as a young doctor had cared for patients devastated by poverty, devoted much of his career to teaching people about how the world has changed. He fought to convince others that extreme poverty in some parts of the world could be eliminated by 2030 , and that the rise in lifespan and drop in family size globally over the past 50 years inspired hope for further progress. His fact-backed sense of optimism influenced leaders ranging from Melinda and Bill Gates to Fidel Castro.

\section{MRI pioneer}

British physicist Peter Mansfield, who helped to develop magnetic resonance imaging (MRI), died on 8 February at the age of 83 . Mansfield (pictured) shared the 2003 Nobel Prize in Physiology or Medicine with US chemist Paul Lauterbur for their pioneering work on MRI scanning, a non-invasive technique now widely used for diagnosing organ diseases. In

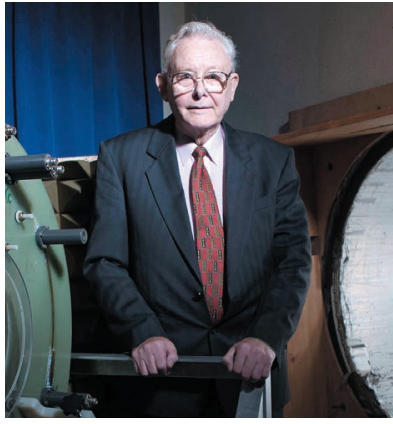

1978, he was the first person to climb into a whole-body MRI machine, ignoring safety concerns, to have his abdomen imaged. Mansfield retired in 1994 from the University of Nottingham, UK, but he continued to collaborate with colleagues at its magnetic resonance centre until his death.

\section{EVENTS}

\section{Turkish purge}

In the Turkish government's latest crackdown on academic freedom following the failed coup last July, another 330 staff were sacked last week from their university positions. The researchers are among more than 4,400 civil servants, including many teachers, whose dismissal President Recep Tayyip Erdoğan had ordered on 7 February by emergency decree. On 10 February, police violently dispersed hundreds who had peacefully gathered outside

\section{TREND WATCH}

Generation capacity for renewable energy in the United States has more than tripled in the past decade, reaching a record 141 gigawatts $(\mathrm{GW})$ in 2016, excluding hydropower. The increase comes mainly from new wind- and solar-power installations, whose capacity has almost quintupled since 2008, from 26 to $123 \mathrm{GW}$. With hydropower, renewable energy met $15 \%$ of US electricity demand last year, up from just $8 \%$ a decade ago, whereas coal's share fell from almost $50 \%$ to $30 \%$.

\section{SUNNY OUTLOOK}

Wind and a burgeoning solar industry are boosting clean energy growth in the United States.

a Geothermal Biomass, biogas, waste-to-energy Solar $\square$ Wind

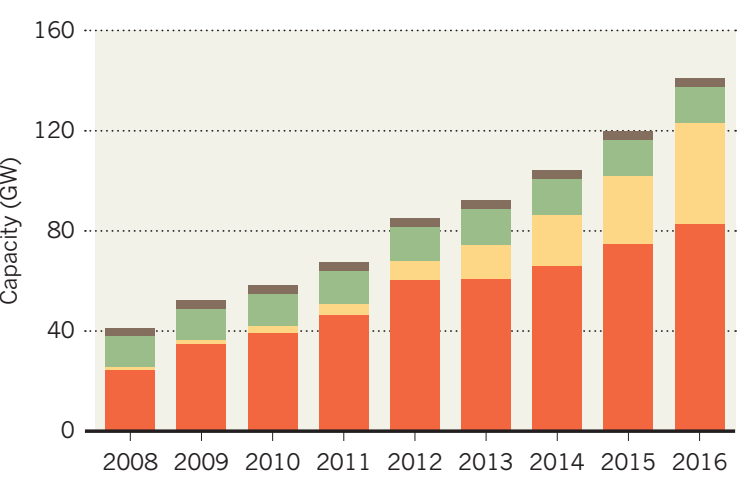

COMING UP

19-23 FEBRUARY

Scientists examine progress towards eliminating malaria at a meeting in Kampala, Uganda. go.nature.com/2kan6pG

\section{0-22 FEBRUARY}

An international conference in Baltimore Maryland, discusses benefits and limitations of vaccines for disease prevention and control. go.nature.com/2kayktl

Ankara University to protest against the dismissals. Many of the sacked academics had last year signed a petition calling on the government to end military operations in Turkey's southeast. See pages 271 and 286 for more.

\section{Suspected fraud}

A South African researcher was arrested in Washington DC last week for alleged complicity in stealing US grant money meant to improve HIV/AIDS treatment in poor countries. Eugene Sickle, former deputy executive director of the Wits Reproductive Health and HIV Institute in Johannesburg, stands accused of having helped a third party to submit fake invoices worth around US\$230,000 to the US Agency for International Development. Sickle quit his post last May after the University of the Witwatersrand, which hosts the institute, questioned him about the allegations. The case is being prosecuted in the United States and a criminal case against Sickle has also been lodged in South Africa. The Washington DC federal public defender who represents Sickle declined to comment on the pending case. 